\title{
Description of Eimeria motelo sp. n. (Apicomplexa: Eimeriidae) from the Yellow Footed Tortoise, Geochelone denticulata (Chelonia: Testudinidae), and Replacement of Eimeria carinii Lainson, Costa \& Shaw, 1990 by Eimeria lainsoni nom. nov.
}

\author{
Lada Hưrková, David Modrý*/+, Břetislav Koudela*, Jan Šlapeta \\ Department of Parasitology, University of Veterinary and Pharmaceutical Sciences, Brno, Czech Republic \\ *Institute of Parasitology, Academy of Sciences of the Czech Republic, Branišovská 31, \\ 37005 České Budějovice, Czech Republic
}

Eimeria motelo sp. $n$. is described from faeces of the yellow-footed tortoise, Geochelone denticulata (L.). Oocysts are irregularly ellipsoidal or cylindrical, with slightly expressed lobed protrusions and irregularities at the poles, possibly caused by wrinkling of the oocyst wall, 17(15-19) × 9.4 (8.5-11) $\mu$ m, shape index (length/width) being 1.81 (1.45-2). The oocyst wall is smooth, single-layered, $0.5 \mu$ m thick with no micropyle. There are no polar bodies. Sporocysts are ellipsoidal, $8.9(7.5-10) \times 4.4(4-5) \mu m$, shape index 2.03 (1.7-2.5). A sporocyst residuum is present, composed of many granules of irregular size. The sporozoites are elongate, lying lengthwise in the sporocysts. Comparison with other species of the genus Eimeria parasitising members of family Testudinidae indicates that the presently described coccidium represents a new species. The name of Eimeria carinii Lainson, Costa \& Shaw, 1990 is found to be preoccupied by a homonym, Eimeria carinii Pinto 1928 given to a coccidium from Rattus norvegicus. Therefore, it is replaced by Eimeria lainsoni nom. nov.

Key words: Eimeria motelo sp. n. - Eimeria lainsoni nom. nov. - Geochelone denticulata - Peru

The yellow footed tortoise, Geochelone denticulata (L.), locally known as "jaboti", "motelo", "morrocoy" or "sigrilpatoe" is a middle sized herbivorous tortoise living in dense rain forests of South America. The yellow-footed tortoises are popular pets and as such are often kept in captivity. The only named coccidian parasites reported from this tortoise are Eimeria jaboti and E. carinii (Carini 1942, Lainson et al. 1990). Here we present a description of a new species of Eimeria originated from Geochelone denticulata from Peru.

\section{MATERIALS AND METHODS}

Four subadult yellow-footed tortoises captured by local people from Tamshiyacu in the Iquitos region of Peru, were recently imported by a private herpeto-keeper in the Czech Republic. The

This study was supported by grant no. A6022903 of the Grant Agency of the Academy of Sciences of the Czech Republic.

${ }^{+}$Corresponding author. Fax: +420-5-748841. E-mail: modryd@vfu.cz.

Received 3 January 2000

Accepted 22 March 2000 animals were quarantined separately in plastic cages and fed on various fruits and vegetables. Faecal samples were collected daily for routine parasitological examination. Individual samples were concentrated by centrifugation-flotation in modified Sheather's sugar solution (sp. gr. 1.3). Samples containing coccidian oocysts were mixed with $2.5 \%$ aqueous $(\mathrm{w} / \mathrm{v})$ potassium dichromate $\left(\mathrm{K}_{2} \mathrm{Cr}_{2} \mathrm{O}_{7}\right)$ solution and spread in a thin layer in covered Petri dishes at $20-23^{\circ} \mathrm{C}$ till the oocysts sporulated. Coccidian oocysts were examined and photographed using Nomarski interference-contrast microscopy (NIC). Measurements were made using a calibrated ocular micrometer and are reported in micrometers as means, followed by the ranges in parentheses.

\section{RESULTS}

Repeated coprological examination revealed the presence of oocysts of a previously undescribed coccidian species belonging to the genus Eimeria in two of the four tortoises, and described below.

\section{Eimeria motelo sp. $\mathrm{n}$.}

Figs 1-7

Description: oocysts irregularly ellipsoidal, with slightly expressed lobed protrusions and irregularities at the poles, possibly caused by wrinkling of 


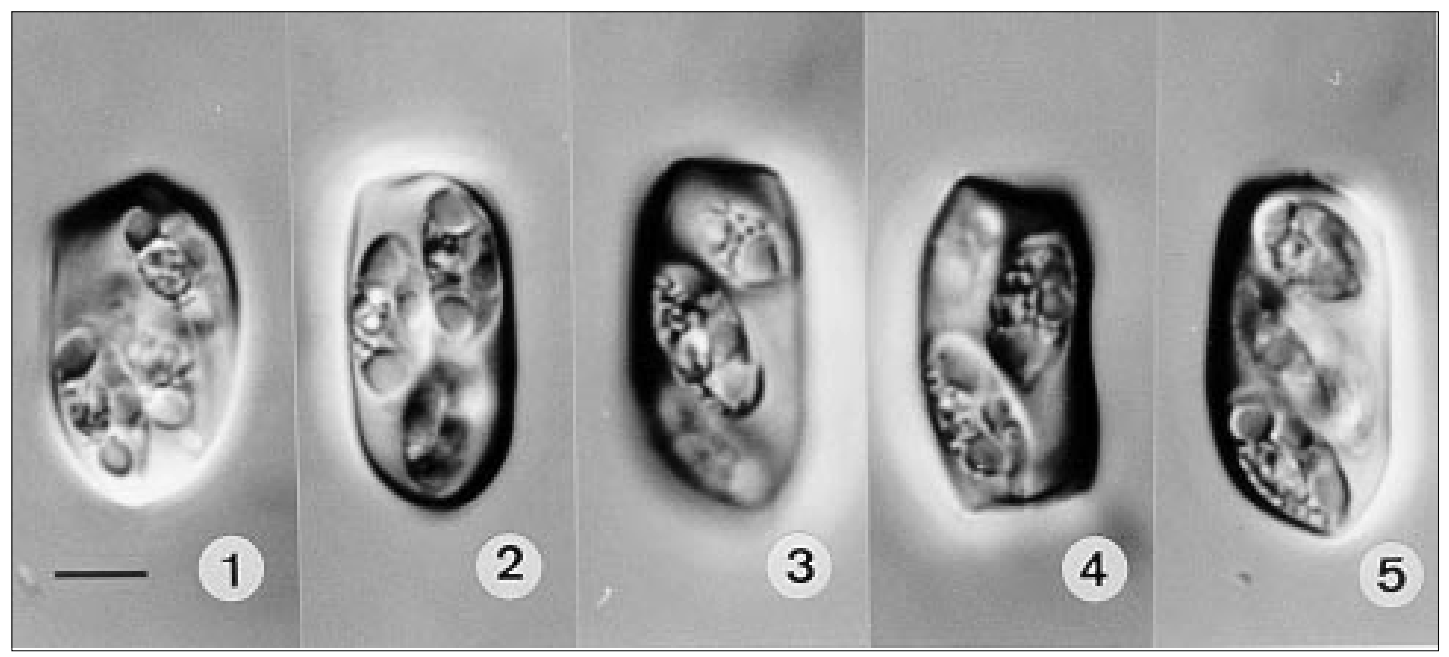

Figs 1-5: Nomarski interference contrast photographs of sporulated oocysts of Eimeria motelo sp. n. showing various oocyst shapes, all in the same scale. $\mathrm{Bar}=5 \mu \mathrm{m}$

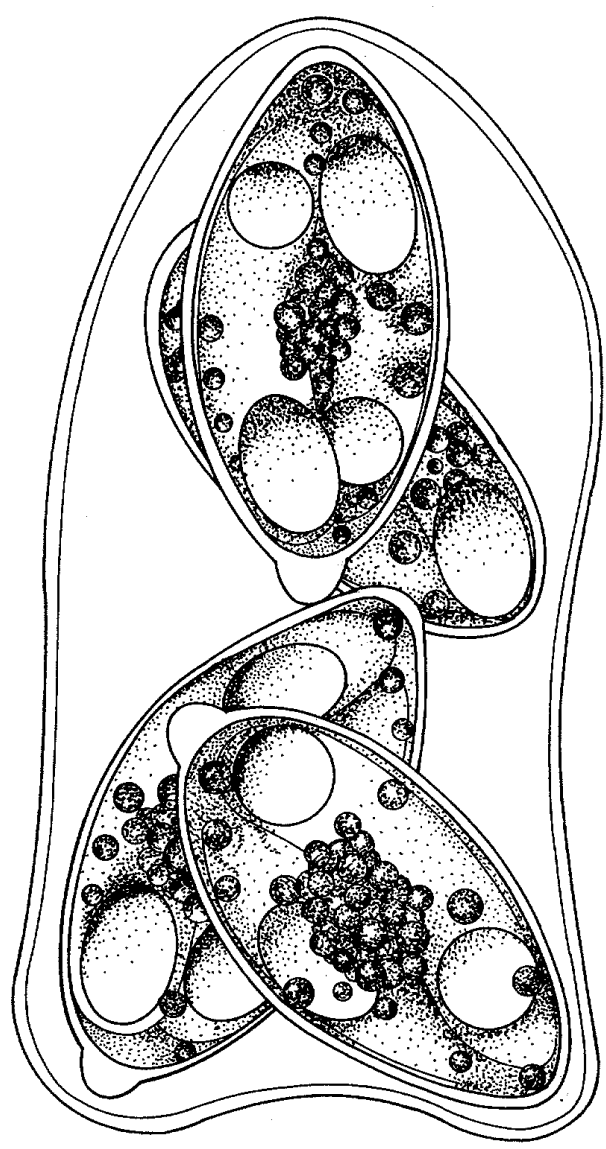

Fig. 6: composite line drawing of sporulated oocyst of Eimeria motelo sp.n. Bar $=5 \mu \mathrm{m}$ oocyst wall. Oocysts are $17(15-19) \times 9.4(8.5-11)$, shape index (SI, length/width) 1.81 (1.45-2). Oocyst wall smooth, single-layered, $\sim 0.5$ thick. Micropyle, oocyst residuum and polar granules absent. Sporocysts ellipsoidal, $8.9(7.5-10) \times 4.4(4-$ 5); SI 2.03 (1.7-2.5). Stieda body present, domelike, $\sim 1 \times 1$; substieda body indistinct. Sporocyst residuum present, composed of small granules of irregular size, organised either in a globular cluster, 3-3.5 in diameter, or scattered individually among sporozoites. Sporozoites elongate, with two refractile bodies.

Type-host: the yellow-footed tortoise, Geochelone denticulata (Linnaeus, 1766) (Reptilia: Chelonia: Testudinidae).

Type-locality: Tamshiyacu, Iquitos, Depertamento de Loreto, Peru (35'ㅇ' $73^{\circ} 10^{\prime} \mathrm{W}$ ).

Prevalence: 2/4 (50\%).

Sporulation: probably endogenous. Oocyst were sporulated 3-4 $\mathrm{h}$ after defecation.

Site of infection: unknown, oocysts recovered from faeces.

Type-material: phototypes are deposited at Institute of Parasitology, Academy of Sciences of the Czech Republic, Branišovská 31, České Budějovice, Czech Republic (No. R 111/99).

Etymology: the specific epithet motelo reflects the local name of the host "motelo" and is given, in accordance with International Code of Zoological Nomenclature (Article 31.1), as a noun in apposition (ICZN 1999).

\section{DISCUSSION}

To date, there are five species of Eimeria and one species of Isospora described and named from 
TABLE

Comparative morphological data on species Eimeria and Isospora described to date from members of family Testudinidae (all measurements in $\mu$ m)

\begin{tabular}{|c|c|c|c|c|c|}
\hline Species & Type host & Oocysts & Sporocysts & Locality & Reference \\
\hline E. brodeni & Testudo graeca & Ovoid, $30(28-32) \times 19(18-20)$ & Ellipsoidal, $10 \times 6-7$ & Greece & Cerruti 1930 \\
\hline E. geochelona & Geochelone nigra & $\begin{array}{l}\text { Ellipsoidal-ovoid, } 21.6(18-25) \times 18.1 \\
(16.0-20.0), \text { OW bi-layered smooth, PG+ }\end{array}$ & $\begin{array}{l}\text { Ellipsoidal, } 10.7(8-12) \times 7(5-8) \text {, } \\
\text { SB+, SSB- }\end{array}$ & $\begin{array}{l}\text { Ecuador } \\
\text { Galápagoos } \\
\text { Isla Santa Cruz }\end{array}$ & Couch et al. 1996 \\
\hline E. jaboti & G. denticulata & $\begin{array}{l}\text { Spherical-subspherical, 17-19 × 15-17, } \\
\text { OW 3-layered, PG+ }\end{array}$ & Oval, $10-11 \times 6-6.6, \mathrm{SB}-$ & Brazil & Carini 1942 \\
\hline $\begin{array}{l}\text { E. lainsoni } \\
\text { nom. nov. }\end{array}$ & G. denticulata & $\begin{array}{l}\text { Spherical-subspherical, } 19.2(15-20) \times 18.6 \\
(14-19) \text {, OW single-layered, smooth, } \\
\text { colourless, PG- }\end{array}$ & $\begin{array}{l}\text { Ellipsoidal, } 8.8(8-9) \times 7.3(7-7.5) \text {, } \\
\text { SB- }\end{array}$ & Brazil & Lainson et al. 1990 \\
\hline E. motelo sp. n. & G. denticulata & $\begin{array}{l}\text { Irregularly elipsoidal, } 17(15-19) \times 9.4 \\
(8.5-11.0) \text {, OW single-layered, smooth, } \mathrm{PG}-\end{array}$ & $\begin{array}{l}\text { Ellipsoidal, } 8.9(7.5-10) \times 4.4(4-5) \text {, } \\
\text { SB+ }\end{array}$ & $\begin{array}{l}\text { Tamshiyacu, } \\
\text { Iquitos, Peru }\end{array}$ & This study \\
\hline E. paynei & Gopherus polyphemus & $\begin{array}{l}\text { Ellipsoidal, } 23.2(19-26) \times 18.6(16-20) \text {, } \\
\text { OW bi-layered, PG+ }\end{array}$ & Ovoid,13.2 (12-14) × $8.1(7-9), S B+$ & USA, Georgia & Ernst et al. 1971 \\
\hline Isospora testudae & T. horsfieldi & $\begin{array}{l}\text { Spherical, } 25.6 \text { (22.1-28.9), OW bi-layered, } \\
\text { smooth, PG- }\end{array}$ & Ovoid, $15.3-18.7 \times 10.2-15.3$, SB- & Uzbekistan & Davronov 1985 \\
\hline
\end{tabular}

OW: oocyst wall, PG: polar granule, SB: stieda body, SSB: substieda body 


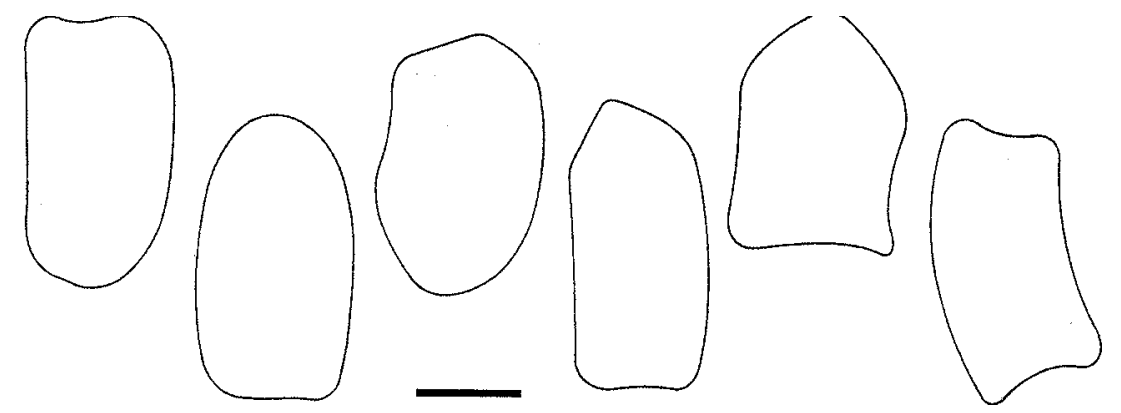

Fig. 7: schematic line drawings showing various shapes of sporulated oocyst of Eimeria motelo sp.n. Bar $=5 \mu \mathrm{m}$

Testudinidae (Cerruti 1930, Carini 1942, Ernst et al. 1971, Davronov 1985, Lainson et al. 1990, Couch et al. 1996): Eimeria brodeni Cerruti 1930 described from Greek tortoise, Testudo graeca; $E$. geochelona Couch, Stone, Duszynski, Snell \& Snell 1996 from Galápagos tortoise, Geochelone nigra; E. paynei Ernst, Fincher \& Stewart, 1971 from gopher tortoise, Gopherus polyphemus; E. jaboti Carini 1942 described from yellow-footed tortoise, Geochelone denticulata; E. carinii Lainson, Costa \& Shaw, 1990 from yellow-footed tortoise, Geochelone denticulata; Isospora testudae Davronov 1985 from Horsfield's tortoise, Testudo horsfieldi. Additionally, an intranuclear coccidian was found and described in various tissues of the radiated tortoise, Geochelone radiata by Jacobson et al. (1994). Oocysts were not found in faeces and generic determination of this parasite therefore remains unknown.

Based on oocyst morphology, E. motelo differs significantly from all of these species (see Table) and is therefore considered as a new species.

Lainson et al. (1990) described $E$ carinii from yellow-footed tortoise, $G$. denticulata from Brazil. However, we have found that the name given for this parasite is preoccupied by a homonym, $E$. carinii Pinto 1928 given to a coccidian from Rattus norvegicus. It is, therefore, proposed that Eimeria carinii Lainson, Costa \& Shaw, 1990 be replaced by the name Eimeria lainsoni nom. nov., which is given in honour of Professor Ralph Lainson.

Except of above mentioned study of Jacobson et al. (1994) describing enteritis, hepatitis, nephritis and pancreatitis associated with a coccidian infection, there are no reports on pathogenicity of coccidian infection for tortoises. Both tortoises expelling coccidian oocysts during the present study showed no signs of alteration in their health status. However, the debilitating effect of coccid- ian infection on tortoises in captivity can not be excluded, particularly in juveniles.

\section{ACKNOWLEDGEMENT}

To SJ Upton for kind help in collecting pertinent literature.

\section{REFERENCES}

Carini A 1942. Sobre uma Eimeria da "Testudo tabulata”. Arq Biol (São Paulo) 26: 163-164.

Cerruti C 1930. Su di un coccidio parassita di Testudo graeca, Linn. Arch Italiano di Scien Med Colon Parassitol 11: 328-331.

Couch L, Stone PA, Duszynski DW, Snell HL, Snell HM 1996. A survey of the coccidian parasites of reptiles from islands of the Galapagos archipelago: 1990-1994. J Parasitol 82: 432-437.

Davronov O 1985. Coccidia of reptiles from southern Uzbekistan. Parazitologiya (Leningrad) 19: 158-161.

Ernst JV, Fincher GT, Stewart TB 1971. Eimeria paynei sp. n. (Protozoa: Eimeriidae) from the Gopher tortoise, Gopherus polyphemus. Proc Helminthol Soc Wash 38: 223-224.

ICZN 1999. International Code of Zoological Nomenclature. 4th ed., International Trust for Zoological Nomenclature, London, xxix+306 pp.

Jacobson ER, Schumacher J, Telford SR, Greiner EC, Buergelt CD, Gardiner CH 1994. Intranuclear coccidiosis in radiated tortoises (Geochelone radiata). J Zoo Wildl Med 25: 95-102.

Lainson R, Costa AM, Shaw JJ 1990. Eimeria species (Apicomplexa: Eimeridae) of Podocnemis expansa (Schweigger) and Geochelone denticulata (Linn.) from Amazonian Brazil (Reptilia: Chelonia). Mem Inst Oswaldo Cruz 85: 383-390.

McAllister CT, Upton SJ 1989. The coccidia (Apicomplexa: Eimeriidae) of testudines, with descriptions of three new species. Can J Zool 67: 24592467.

Pinto C 1928. Eimeria carinii nova especie. Parasita de Mus (E.) norwegicus do Brasil. Bol Biol (S. Paulo) 11-14: 127-128.

Additional literature cited on the coccidia of tortoises can be found at http://biology001.unm.edu/ coccidia/home.html. 